\title{
Words in haematology and wine
}

\author{
Shaun McCann $\mathbb{1}^{1}$
}

Received: 15 September 2020 / Revised: 22 September 2020 / Accepted: 7 October 2020 / Published online: 17 October 2020

(c) The Author(s), under exclusive licence to Springer Nature Limited 2020

What's in a name?

William Shakespeare's Romeo and Juliet.

English bard. (1564-1616)

Names can last unchanged for a long time, change their meaning or be changed in what is known as 'colonial appropriation' i.e., the changing of place names into the colonist's language. In medicine, Latin names tend to stick but the names of procedures may change over time. Think, for a while about the procedure of bone marrow transplantation. When I learnt to be a 'transplanter' in the Fred Hutchinson Cancer Research Centre, known locally as 'The Hutch' the source of haematopoietic cells was bone marrow, but this has subsequently morphed into mobilised peripheral blood and umbilical cord blood. However, the terms haematopoietic cell transplantation (HCT) or haemopoietic stem cell transplantation are now widely used in order to cover all sources of cells.

Some organisations have managed to change their name but keep their acronym, for example the EBMT. This organisation began as the European Cooperative Group for Bone Marrow Transplantation, changed to the European group for Blood and Bone Marrow Transplantation and subsequently, The European Society for Blood and Bone Marrow Transplantation while still retaining its acronym. The American Society for Blood and Marrow Transplantation has not been so lucky and has changed to The American Society for Transplantation and Cellular Therapy. It is too soon to measure the effect of this change. However, some things don't change, for example, this journal is still called Bone Marrow Transplantation even though many published articles refer to transplants using mobilised peripheral blood or umbilical cord blood as a source of haematopoietic cells.

Shaun McCann

shaunrmccann@gmail.com

1 Haematology Emeritus, University of Dublin Trinity College, Dublin, Ireland
When I was the chairman of the Bone Marrow for Leukaemia Trust (BMLT), a registered charity which supports HCT in Ireland, the board agonised about changing its name to more accurately reflect the changes occurring in the specialty. After much discussion it was felt that the brand name BMLT was so well known to the public that a new name might confuse supporters and result in a reduction of financial support.

In medicine, I suppose, the most widely abused term is $\mathrm{X}$-ray (x-rays are invisible) when the term radiograph should be used. The word X-ray is used (misused) so frequently that there is probably no point in trying to re-instate the correct term. I have tried, many times, but in vain, to explain the difference between symptoms and signs [1] but that battle also seems to be lost. I was reduced to putting pen to paper (I actually used a computer) when a journalist in a prestigious English newspaper ascribed symptoms to an economy [2]. Another quaint expression in Ireland is that patients who require intravenous support are described as being 'put on a drip'. I thought this ridiculous expression was redundant until I heard a doctor using it recently on the national radio.

The words 'left' and 'right' are terms we are all familiar with when discussing politics but according to McNally [3], writing in the Irish Times, the terms originated during the French revolution when radicals sat on the 'left' and conservatives on the 'right' of the chamber at the National Convention. Both words may be used disparagingly by those from the other side however, they are often difficult to apply to contemporary political movements. Other terms that can be used to disparage are 'Bourgeois' or 'Bourgeoisie'. They are usually used in a pejorative sense to indicate the 'middle class' who putatively have a purely mercantile mentality. The term was popularised by JeanBaptiste Poquelin more commonly known as Molière (1622-1673) Fig. 1 the favourite playwright of King Louis XIV. His play 'Le Bourgeois gentilhomme' has been commented on by critics as an oxymoron as there can't be a gentleman (one of noble birth) who is also a member of the 'Bourgeoisie'. Other critics interpret the play as an insult to 
Turkey and the Ottoman Empire. The play was first staged in Château Chambord Fig. 2 in the Loire Valley, which also houses a famous double helix stairway, the design of which is attributed to Leonardo da Vinci.

However, the man who is most widely associated with the term, Bourgeoisie, is Karl Marx (1818-1883). Marx claimed that the Bourgeoisie was the oppressive class which controlled the means of production during the industrial revolution and who wished to ensure their economic

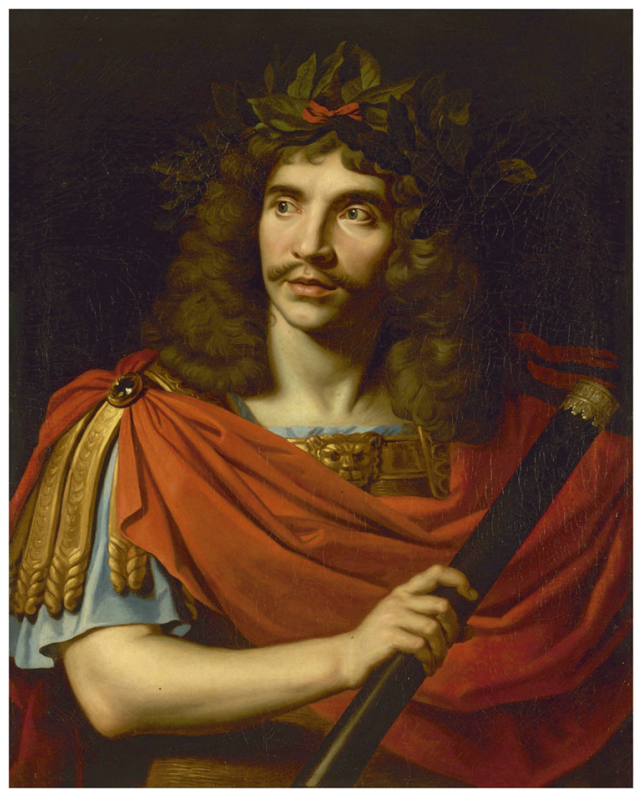

Fig. 1 Jean-Baptiste Poquelin. He was known by his stage name Molière. (1622-1673) By Nicolas Mignard (1606-1668). superiority in society. He maintained that the Bourgeoisie would be destroyed in the workers revolution. In the 20th century the surreal film 'The Discrete Charm of the Bourgeoisie' by Louis Buñuel (1972) depicts a group of Bourgeoisie attempting to have dinner but never succeeding. He exposes their sense of entitlement, hypocrisy and corruption. The film enjoys 'cult' status in certain circles.

What has this to do with wine? Cru Bourgeois, Fig. 3 is a term given to certain wines from Bordeaux. Although not as good as Grand Cru or Premier Cru wines they are of a very high standard and are often excellent value for money (I must be one of the Bourgeoisie!). They come from the

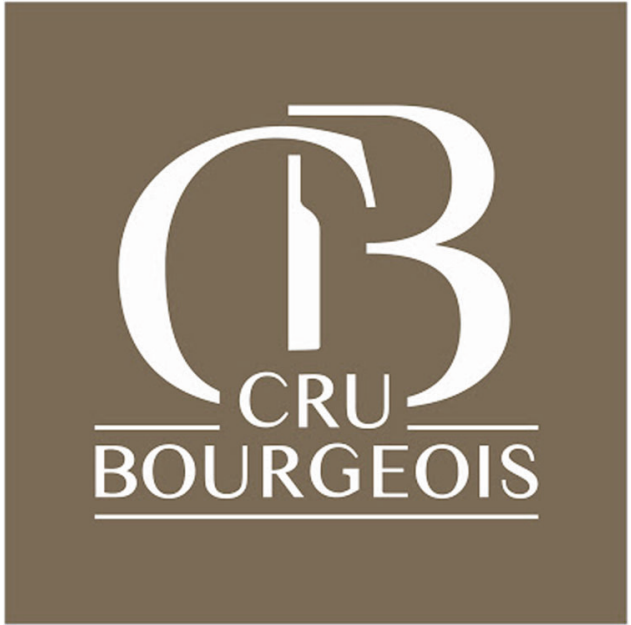

Fig. 3 Cru Bourgeois label. This label is now on all bottles of classified wine.
Fig. 2 Château at Chambord in the Loire Valley. The play Le Bourgeois gentilhomme was first performed here for King Louis XIV.

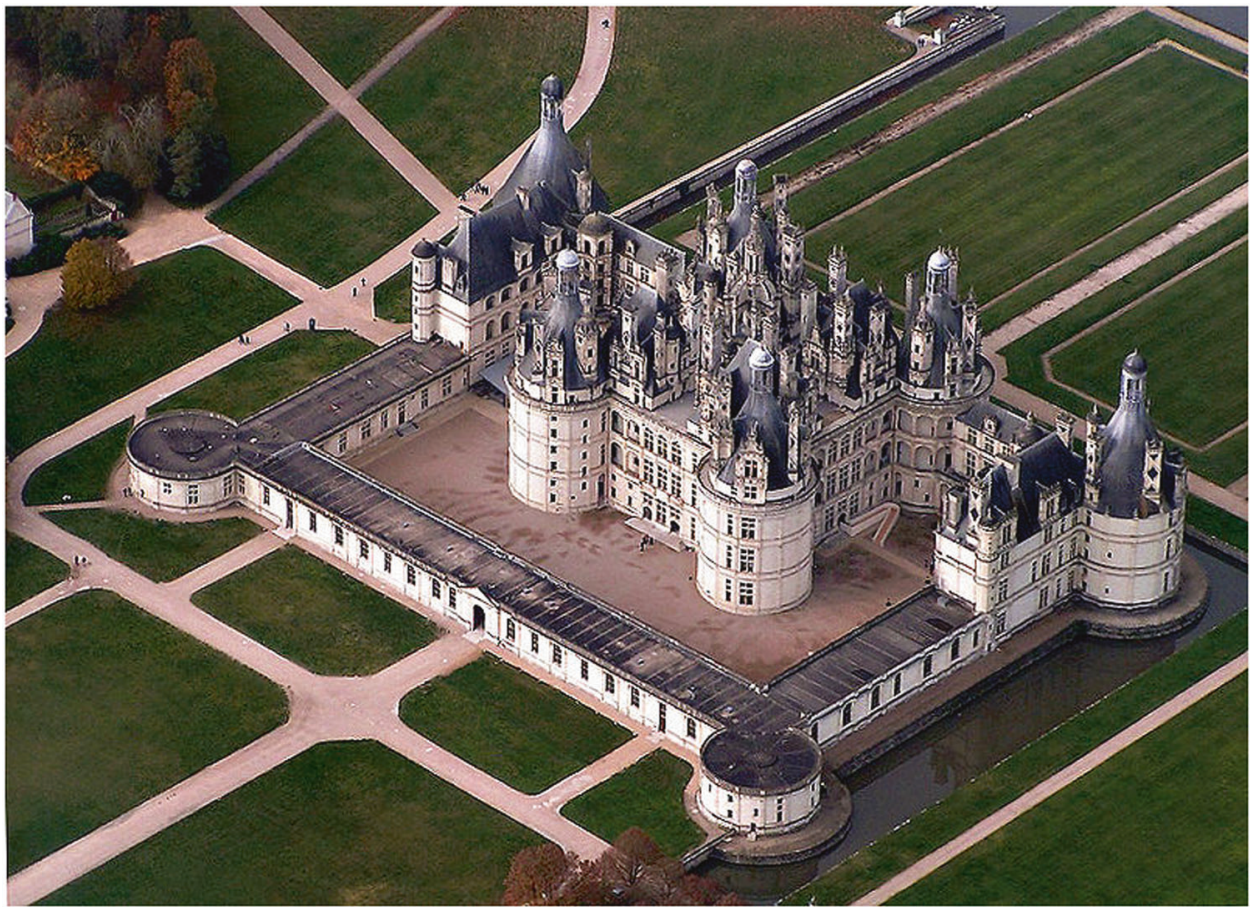


Médoc, Haut-Médoc, Listrac, Margaux, Saint-Julien, Pauillac and Saint-Estèphe (nothing on the right bank). Crus Bourgeois wines have a rather chequered history, however a little work may reveal some excellent wines. The term Cru Bourgeois goes back to the reign of Louis XIV (that man again) when châteaux were beginning to be owned by nonaristocrats but the term never became official. In 1932, the Bordeaux Chamber of Commerce chose 444 wines to be part of the Cru Bourgeois group but, again, the legislation never became official. In 2000, 247 châteaux were part of a new group but a lot of internal dissent ensued, resulting in the banning of Cru Bourgeois on wine labels. In 2010, each château had to re-apply annually for membership, and the 2008 vintage released in 2010 were the first bottles to carry the official Cru Bourgeois label. In 2020 The Alliance des Crus Bourgeois du Médoc decided that there should be three tiers, Cru Bourgeois, Cru Bourgeois supérieur and Cru Bourgeois exceptional but the classification applies to the château and not the wine [4].

Put your wine merchant under a little pressure to find these wines and you'll be pleased with the result. I have just taken delivery of a case of Château Beaumont, 2016,
Haut-Médoc, Cru Bourgeois supérieur. I haven't tasted it yet but am looking forward to consuming some of it with my Christmas dinner.

So, if you want to be disparaging and call someone a Bourgeoisie at least know the derivation of the word.

\section{Compliance with ethical standards}

Conflict of interest The author declares that he has no conflict of interest.

Publisher's note Springer Nature remains neutral with regard to jurisdictional claims in published maps and institutional affiliations.

\section{References}

1. McCann S. Symptoms and signs. Bone Marrow Transpl. 2019. https://doi.org/10.1038/s41409-018-0425-9.

2. McCann S. Economies, like babies cannot have symptoms. London, UK: The Financial Times Ltd; 2020.

3. McNally F. An Irishman's diary. Dublin, Ireland: The Irish Times Ltd; 2020.

4. Harding JMW. A brand-new cru bourgeois classification. 2020. www.jancisrobinson.com/articles. 